\title{
Hepatitis B Virus-Related Hepatocellular
} Carcinoma

National Cancer Institute

\section{Source}

National Cancer Institute. Hepatitis B Virus-Related Hepatocellular Carcinoma. NCI

Thesaurus. Code C27687.

A hepatocellular carcinoma that develops following hepatitis B virus exposure and injury of the liver parenchyma. 